\title{
OPEN Synergistic interaction of renewable nipagin and eugenol for aromatic copoly(ether ester) materials with desired performance
}

\author{
Keling $\mathrm{Hu}^{1 凶}$, Huachao Sui \& Dongping Zhao ${ }^{2}$
}

Naturally occurring nipagin and eugenol were used as the collaborative starting materials for poly(ether ester) polymers. In this study, two series of nipagin and eugenol-derived copoly(ether ester)s, $\mathrm{PHN1}_{1-\mathrm{x}} \mathrm{E1_{ \textrm {x } }}$ and $\mathrm{PHN1}_{1-\mathrm{x}} \mathrm{E2} \mathrm{2}_{\mathrm{x}}(\mathrm{x}=0 \%, 5 \%, 10 \%, 15 \%, 20 \%)$, were prepared with renewable 1,6-hexanediol as a comonomer. The nipagin-derived component acts as the renewable surrogate of petroleum-based dimethyl terephthalate (DMT), while the eugenol-derived component acts as the cooperative property modifier of parent homopoly(ether ester) PHN1. 1,6-Hexanediol was chosen as the spacer because of its renewability, high boiling point, and short chain to enhance the glass transition temperatures $\left(T_{\mathrm{g}} \mathrm{s}\right)$ of materials. The molecular weights and chemical structures were confirmed by gel permeation chromatograph (GPC), NMR and FTIR spectroscopies. Thermal and crystalline properties were studied by thermal gravimetric analysis (TGA), differential scanning calorimetric (DSC) and wide-angle X-ray diffraction (WXRD). The tensile assays were conducted to evaluate the mechanical properties. The results suggested that properties of this kind of poly(ether ester)s could be finely tuned by the relative content of two components for the desired applications (elastomer, rubbery) suitable for different scenarios from polyethylene glycol terephthalate (PET) and polybutylene terephthalate (PBT).

Currently, great majority of plastic consumed globally is produced from fossil resources. This situation brings about the gradual depletion of non-renewable materials, as well as increasingly severe environmental concerns ${ }^{1-6}$. The reality prompts us to find bio-based substitutes to petroleum-based resources from the view of sustainable development ${ }^{7-11}$. PET and PBT are representative examples of widely used engineering plastics, but they are mainly produced from petroleum-based dimethyl terephthalate (DMT). Due to the huge consumption, finding the renewable surrogates for DMT without sacrificing the thermal stability and mechanical strength of materials is urgent.

Nipagin and eugenol are two naturally occurring building blocks, which exist in campanulaceae plant and clove, respectively ${ }^{12,13}$. These two starting materials have been found widespread applications in fields of liquid crystalline material $^{14,15}$, epoxy resin ${ }^{16-18}$, benzoxazine ${ }^{19,20}$, coating $^{21,22}$, and Li-S battery ${ }^{23}$. Because of the multifunctionality (phenol and vinyl) and renewability of nipagin and eugenol, based on them our group has been dedicated to polyester materials, whose thermal, crystalline, mechanical and degradable properties have been comprehensively investigated ${ }^{24,25}$. The influence of monomer structure on final properties was also studied ${ }^{26}$. However, the comprehensive performance of obtained polyesters can still be improvable, regardless of the renewability of starting materials. Either the glass transition temperatures $\left(T_{\mathrm{g}} \mathrm{s}\right)$ were not high enough, or the mechanical tough and strength was not perfect. Consequently, further optimizing the performance of nipagin and eugenol-based polymer materials is particularly important for the development and utilization of such materials.

Considering the structural difference of nipagin and eugenol, the symmetrical nipagin units can endow the polymers with high crystallinity and mechanical strength, but poor flexibility and ductility ${ }^{27,28}$. In contrast, eugenol-derived unit is highly asymmetrical one, which endows the polymers low crystallinity and poor mechanical strength, while their flexibility and ductility are good ${ }^{24}$. Taking advantages of the complementary features of these two building blocks through rational molecular design may give the polymeric materials synergistic effect and desired final properties.

${ }^{1}$ School of Materials Science and Engineering, Tiangong University, Tianjin 300387, People's Republic of China. ${ }^{2}$ School and Hospital of Stomatology, Tianjin Medical University, Tianjin 300070, People's Republic of China. email: hukeling@tiangong.edu.cn 


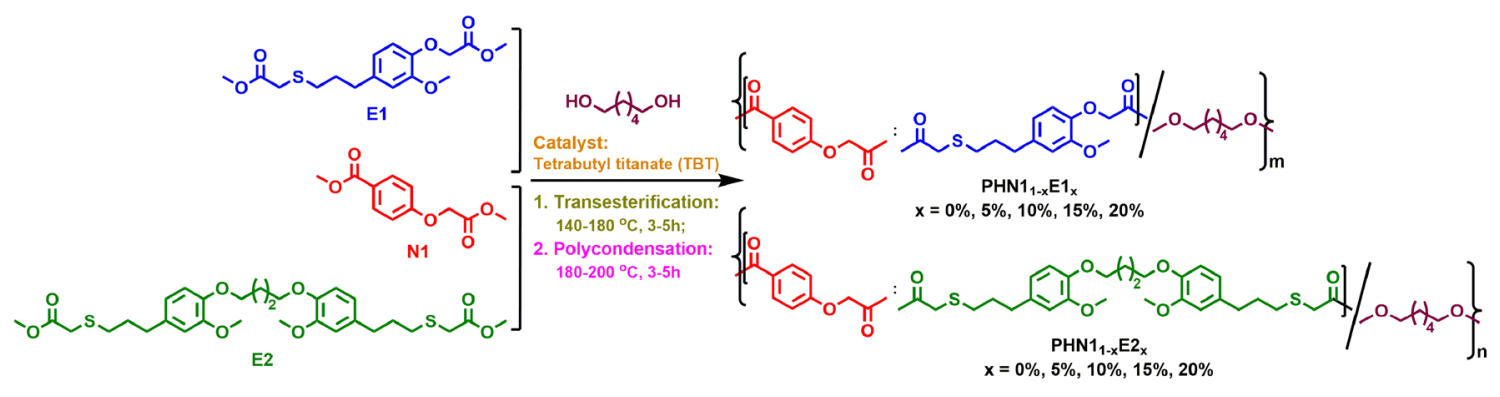

Figure 1. Synthetic procedures for the preparation of nipagin and eugenol-based poly(ether ester)s. The polymerization was performed in a $25 \mathrm{~mL}$ Schleck round-bottom flask equipped with a nitrogen inlet, a vacuum distillation outlet, and a stirrer bar. The catalyst, polymerization temperature and times are indicated in the figure.

\begin{tabular}{|c|c|c|c|c|c|c|c|c|c|c|}
\hline \multirow[b]{3}{*}{ Entry } & \multirow[b]{3}{*}{ Poly(ether ester) } & \multirow[b]{3}{*}{ Yield $(\%)^{c}$} & \multicolumn{4}{|c|}{ Molar composition } & \multirow{2}{*}{\multicolumn{3}{|c|}{ Molecular weight ${ }^{\mathrm{b}}$}} & \multirow[b]{3}{*}{ Isolated appearance $^{c}$} \\
\hline & & & \multicolumn{2}{|c|}{ Feed ratio } & \multicolumn{2}{|c|}{ Final product ${ }^{\mathrm{a}}$} & & & & \\
\hline & & & $X_{\mathrm{N} 1}$ & $X_{\mathrm{E}}$ & $X_{\mathrm{N} 1}$ & $X_{\mathrm{E}}$ & $M_{\mathrm{n}}$ & $M_{\mathrm{w}}$ & Ð & \\
\hline 1 & PHN1 & $92 \%$ & 100 & 0 & 100 & 0 & 14,900 & 26,300 & 1.8 & White powder \\
\hline 2 & $\mathrm{PHN1}_{95 \%} \mathrm{E} 1_{5 \%}$ & $87 \%$ & 95 & 5 & 94.3 & 5.7 & 13,400 & 23,600 & 1.8 & Light yellow powder \\
\hline 3 & $\mathrm{PHN1}_{90 \%} \mathrm{E} 1_{10 \%}$ & $88 \%$ & 90 & 10 & 90.4 & 9.6 & 10,200 & 16,900 & 1.7 & Light yellow powder \\
\hline 4 & $\mathrm{PHN1}_{85 \%} \mathrm{E} 1_{15 \%}$ & $86 \%$ & 85 & 15 & 84.7 & 15.3 & 10,200 & 17,200 & 1.7 & Light yellow powder \\
\hline 5 & $\mathrm{PHN1}_{80 \%} \mathrm{E} 1_{20 \%}$ & $85 \%$ & 80 & 20 & 80.3 & 19.7 & 13,900 & 24,000 & 1.7 & Light yellow semi-solid \\
\hline 6 & $\mathrm{PHN1}_{95 \%} \mathrm{E} 2_{5 \%}$ & $87 \%$ & 95 & 5 & 94.3 & 5.7 & 15,100 & 26,800 & 1.8 & Light yellow powder \\
\hline 7 & $\mathrm{PHN} 1_{90 \%} \mathrm{E} 2_{10 \%}$ & $85 \%$ & 90 & 10 & 89.3 & 10.7 & 13,200 & 22,400 & 1.7 & Light yellow powder \\
\hline 8 & $\mathrm{PHN} 1_{85 \%} \mathrm{E} 2_{15 \%}$ & $86 \%$ & 85 & 15 & 84.0 & 16.0 & 13,200 & 23,000 & 1.7 & Light yellow semi-solid \\
\hline 9 & $\mathrm{PHN}_{80 \%} \mathrm{E} 2_{20 \%}$ & $82 \%$ & 80 & 20 & 78.7 & 21.3 & 11,400 & 19,900 & 1.7 & Light yellow semi-solid \\
\hline
\end{tabular}

Table 1. Molar composition, molecular weight, polydispersity, isolated yield and appearance of the synthesized poly(ether ester)s. ${ }^{a}$ Molar composition in final products determined by the integration of ${ }^{1} \mathrm{H}$ NMR spectra. ${ }^{b}$ Polystyrene (PS) calibrated gel permeation chromatography (GPC) values with tetrahydrofuran (THF) eluent. 'After purification by precipitating from an excess amount of methanol and dried in vacuum overnight.

In this work, three nipagin and eugenol-derived diester monomers were firstly synthesized (Supplementary information, Fig. S1-S8), then melt polycondensation between diester monomers and 1,6-hexanediol were carried out. 1,6-Hexanediol was chosen because of its renewability and high boiling point $\left(250^{\circ} \mathrm{C}, 1 \mathrm{~atm}\right)$ compared with short-chain ethylene glycol $\left(196^{\circ} \mathrm{C}, 1 \mathrm{~atm}\right)$ and 1,4-butanediol $\left(228^{\circ} \mathrm{C}, 1 \mathrm{~atm}\right)^{29-32}$, the low boiling points of which can lead to volatilize easily during the polycondensation stage and be difficult to control the stoichiometric ratio between diester and diol precisely, and thus caused low molecular weights. Meanwhile, due to the chain length of 1,6-hexanediol is shorter than that of 1,10-decanediol, the $T_{\mathrm{g}} \mathrm{s}$ of obtained polymers were enhanced obviously compared with our previously synthesized polyesters with 1,10-decanediol as the spacer ${ }^{26}$. The high $T_{\mathrm{g}}$ values can make polymer materials applied in a wide temperature range. Synergistic effect between these two structurally distinctive components (nipagin and eugenol) endows the materials with desired performance, which can be modulated for a broad range of applications (elastomer, rubbery) suitable for a variety of scenarios.

\section{Results and discussion}

Synthesis and structures of the copoly(ether ester)s. $P H N 1_{1-x} E 1_{x}$ and $P H N 1_{1-x} E 2_{x}$ copoly(ether ester)s were synthesized by a melt polycondensation method according to the predetermined composition ratios of nipagin and eugenol-derived dimethyl ester monomers. The polymerization routes are shown in Fig. 1 and the results are summarized in Table 1. The GPC traces are depicted in Supplementary Fig. S9-S10.

The high yields suggest the high reactivity of the two kinds of monomers. The consistency of nipagin and eugenol-derived units in the feed and final product demonstrates that nipagin and eugenol-based diester monomers have similar reactivity and excellent compatibility. Copoly(ether ester)s with $M_{\mathrm{n}}$ above $10^{4}$ were successfully obtained, and polydispersity $\left(\oslash=M_{\mathrm{n}} / M_{\mathrm{w}}\right)$ values are found to be fixed at about 1.7 regardless of the feed ratios, which also suggest the similar reactivity of diester monomers, where $M_{\mathrm{n}}$ and $M_{\mathrm{w}}$ are the number- and weight-average molecular weights, respectively. The apparent appearance of final products is closely related with the feed ratios. That is, with the gradual increase of eugenol-based units, the physical form of final product changes from white powder for PHN1, transforms into yellow powder for PHN1 $1_{95 \%} \mathrm{E} 1(2)_{5 \%}, \mathrm{PHN}_{90 \%} \mathrm{E} 1(2)_{10 \%}$, and $\mathrm{PHN} 1_{85 \%} \mathrm{E} 1_{15 \%}$, finally becomes light yellow semi-solid for $\mathrm{PHN} 1_{80 \%} \mathrm{E} 1_{20 \%}, \mathrm{PHN} 1_{85 \%} \mathrm{E} 2_{15 \%}$ and $\mathrm{PHN} 1_{80 \%} \mathrm{E} 2_{20 \%}$. This phenomenon indicates that eugenol-derived units are easier to be oxidized than nipagin-derived units. 
(a)
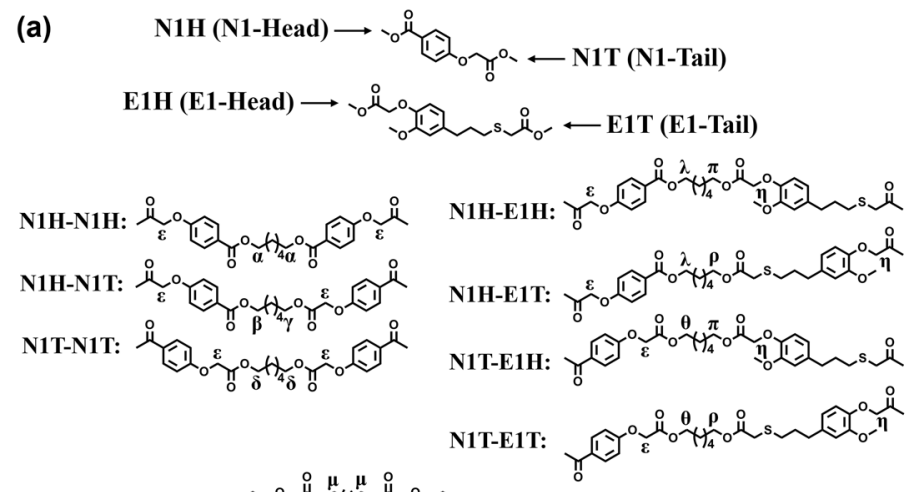

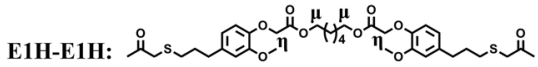

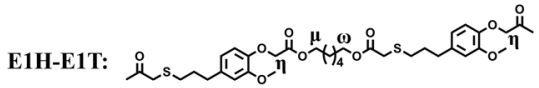

E1T-E1T:
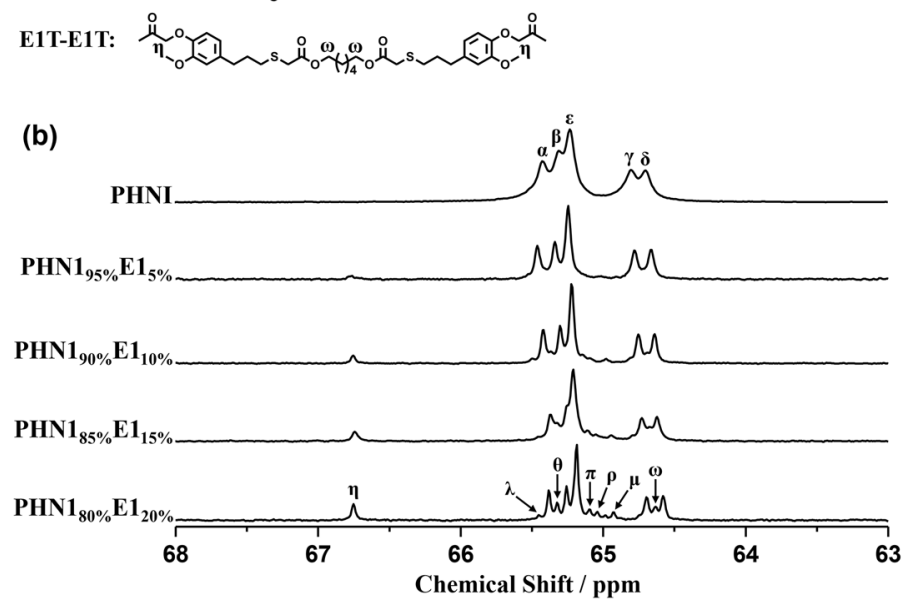

Figure 2. The splitting situations (b) of different carbons under magnetically non-equivalent environment along polymer chains for $\mathrm{PHN1}_{1-\mathrm{x}} \mathrm{E} 1_{\mathrm{x}}$ with the indications of dyads to which they are assigned $(\mathbf{a}) . \mathrm{N} 1 \mathrm{H}$ and $\mathrm{N} 1 \mathrm{~T}$ indicate the head and tail sides of $\mathrm{N} 1 \mathrm{unit}$, while $\mathrm{E} 1 \mathrm{H}$ and $\mathrm{E} 1 \mathrm{~T}$ indicate the head and tail sides of E1 unit. The ${ }^{13} \mathrm{C}$ NMR spectra were recorded in deuterated chloroform $\left(\mathrm{CDCl}_{3}\right)$ at $25^{\circ} \mathrm{C}$ on a Bruker AVANCE III NMR spectrometer operating at $100.6 \mathrm{MHz}$.

As the structural information of polymer chains are closely related to thermal, crystalline and mechanical properties of materials, chemical structures of the copoly(ether ester)s were confirmed by ${ }^{1} \mathrm{H}$ NMR (see Supplementary Fig. S11-S12), ${ }^{13}$ C NMR (see Supplementary Fig. S13-S14) and FTIR spectroscopy (see Supplementary Fig. S15-S16). Furthermore, their chemical microstructures were studied by the quantitative ${ }^{13} \mathrm{C}$ NMR spectra taking advantage of the sensitiveness of magnetically different carbon atoms present in backbones towards sequence distributions at the dyed level ${ }^{33}$. In the present study, the methylene carbons adjacent to the alcoholoxygens were well resolved in the ${ }^{13} \mathrm{C}$ NMR spectra due to the asymmetrical feature of $\mathrm{N} 1$ and E1. They exhibited the difference of head and tail when incorporated into the polymer chains during copolymerizing. However, when N1 was copolymerized with E2, N1 displayed the difference of head and tail while the two ester groups in E2 were equivalent. The possible sequence distributions and splitting situation of methylene carbons in ${ }^{13} \mathrm{C}$ NMR spectra were depicted in Fig. 2 and Supplementary Fig. S17, from which we can observe that the signal intensities depend closely on the feed ratios of copoly(ether ester)s. Due to short chain of 1,6-hexanediol, the splitting of methylene carbons adjacent to the alcohol-oxygens was very sensitive to sequence distributions as shown in the case of $\mathrm{PHN}_{80 \%} \mathrm{E}_{20 \%}$ (Fig. 2b). This analysis suggested that $\mathrm{N} 1$ and $\mathrm{E} 1$ (E2) were incorporated into the copoly(ether ester) chains in an arbitrary manner. Hence, the nipagin and eugenol-derived copoly(ether ester) $s$ have completely random microstructures in polymer mainchains. This randomness may have vital influence on thermal stability, crystallinity, and mechanical strength.

Thermal properties. Thermal stability is an important parameter of polymer materials in practical applications, and determines the long-term usability. In this study, thermal stabilities of the copoly(ether ester)s were investigated by thermogravimetric analysis (TGA). Weight-loss curves and the corresponding derivative curves were depicted in Fig. 3, Fig. 4 and Supplementary Fig. S18-S19, respectively. Thermal property parameters were summarized in Table 2 and the results suggested that $P H N 1_{1-\mathrm{x}} \mathrm{E} 1_{\mathrm{x}}$ and $\mathrm{PHN} 1_{1-\mathrm{x}} \mathrm{E} 2_{\mathrm{x}}$ exhibited comparable thermal stability with the parent PHN1. Despite the content of eugenol-derived composition reached $20 \%$, the temperature at which $5 \%$ weight loss $\left(T_{5 \%}\right)$ decreased just about $12{ }^{\circ} \mathrm{C}$ for both $\mathrm{PHN} 1_{1-\mathrm{x}} \mathrm{E} 1_{\mathrm{x}}$ and $\mathrm{PHN} 1_{1-\mathrm{x}} \mathrm{E} 2_{\mathrm{x}}$ relative 


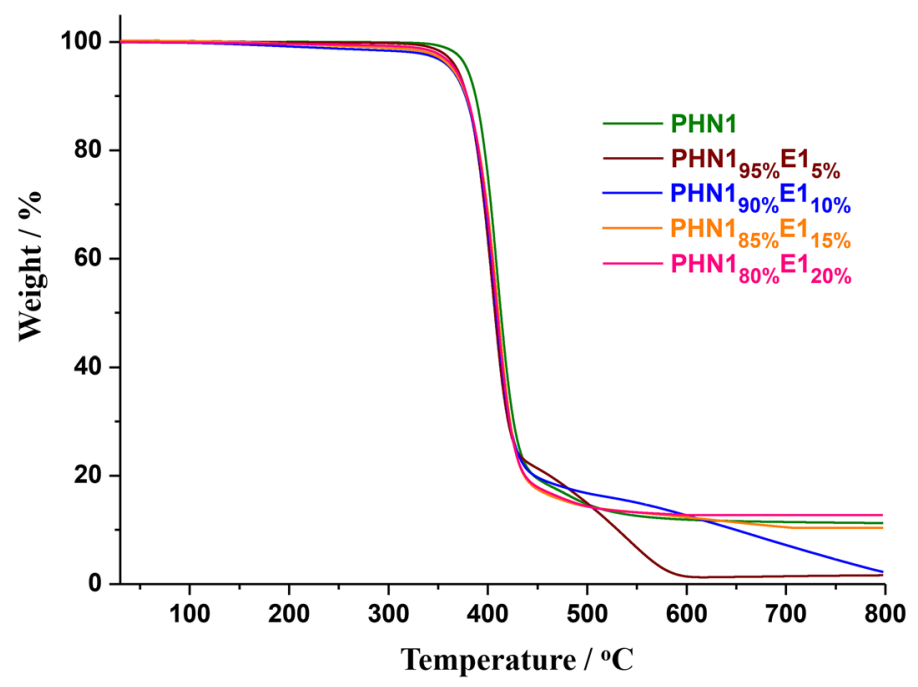

Figure 3. Thermogravimetric analysis (TGA) curves of $P H N 1_{1-x} E 1_{x}$ recorded from $25-800{ }^{\circ} \mathrm{C}$ at a heating rate of $10^{\circ} \mathrm{C} / \mathrm{min}$ under a nitrogen atmosphere.

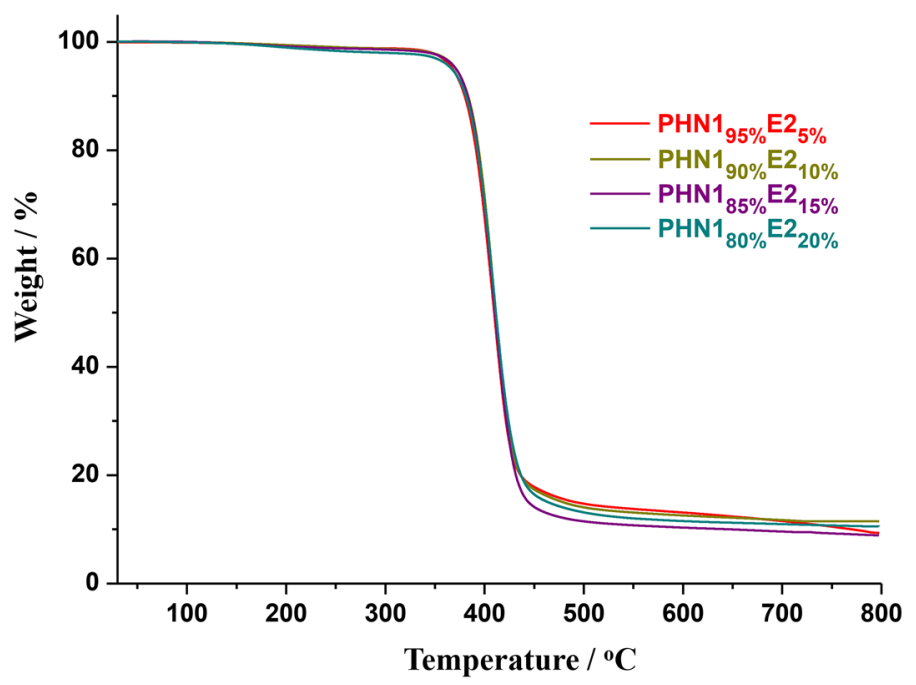

Figure 4. Thermogravimetric analysis (TGA) curves of $\mathrm{PHN} 1_{1-\mathrm{x}} \mathrm{E} 2_{\mathrm{x}}$ recorded from $25-800{ }^{\circ} \mathrm{C}$ at a heating rate of $10^{\circ} \mathrm{C} / \mathrm{min}$ under a nitrogen atmosphere.

to PHN1 (Table 2, entry 1, 5, and 9). Furthermore, $\mathrm{PHN1} 1_{1-\mathrm{x}} \mathrm{E} 1_{\mathrm{x}}$ and $\mathrm{PHN1} 1_{1-\mathrm{x}} \mathrm{E} 2_{\mathrm{x}}$ exhibited almost the same thermal stability regardless of the composition of copoly(ether ester)s. Based on the above results we conclude that the incorporation of eugenol-derived units had little influence on thermal stability of the final product. $T_{5 \%}$ values were above $363^{\circ} \mathrm{C}$ for all the samples, which is comparable with that of the petroleum-based poly(butylene terephthalate) $(\mathrm{PBT})\left(T_{5 \%}=371^{\circ} \mathrm{C}\right)$ with appropriate molecular weights $\left(M_{n}=17,100, \emptyset=2.4\right)$ reported by others $^{34}$. The temperature for maximum degradation rate $\left(T_{\mathrm{d}}\right)$ values were almost identical for both PHN1 and $\mathrm{PHN1}_{1-\mathrm{x}} \mathrm{E} 1(2)_{\mathrm{X}}$, whose $T_{\mathrm{d}}$ values were fixed at about $410{ }^{\circ} \mathrm{C}$ and found to be insusceptible to the changes of content in eugenol-derived composition. Furthermore, $\mathrm{PHN}_{1-\mathrm{x}} \mathrm{E} 1_{\mathrm{x}}$ with eugenol-derived composition below or equal to $10 \%$ featured a two-step degradation mechanism. However, for $\mathrm{PHN}_{1_{-\mathrm{x}}} \mathrm{E} 1_{\mathrm{x}}$ with eugenol-derived composition above $10 \%$ and the whole series of $\mathrm{PHN}_{1-\mathrm{x}} \mathrm{E} 2_{\mathrm{x}}$, single-step degradation was observed. This phenomenon could be explained by the mismatch of conformation of polymer chains at such specific compositions. Conclusion could be drawn from TGA analysis was that the copoly(ether ester)s featured excellent thermal stabilities, and the incorporation of eugenol-derived component actually had good compatibility with the parent PHN1. In a word, these bio-derived materials have excellent thermal stability.

Other thermal properties like glass transition $\left(T_{\mathrm{g}}\right)$, melting and crystallization temperatures $\left(T_{\mathrm{m}}, T_{\mathrm{c}}\right)$, together with their corresponding melting and crystallization enthalpies $\left(\Delta H_{\mathrm{m}}, \Delta H_{\mathrm{c}}\right)$ are critical factors for the shape retention under normal practical use, as well as during molding process. Here these properties were studied by differential scanning calorimetric analysis (DSC). The DSC heating traces (2nd) are shown in Fig. 5, and the analytical data are gathered in Table 2. 


\begin{tabular}{|c|c|c|c|c|c|}
\hline \multirow[b]{2}{*}{ Entry } & \multirow[b]{2}{*}{ Polymers } & \multicolumn{3}{|l|}{ TGA } & \multirow{2}{*}{$\begin{array}{l}\text { DSC } \\
T_{\mathrm{g}}{ }^{\mathrm{d}}\left({ }^{\circ} \mathrm{C}\right)\end{array}$} \\
\hline & & $T_{5 \%}{ }^{\mathrm{a}}\left({ }^{\circ} \mathrm{C}\right)$ & $T_{\mathrm{d}}^{\mathrm{b}}\left({ }^{\circ} \mathrm{C}\right)$ & $W^{c}(\%)$ & \\
\hline 1 & PHN1 & 379 & $409 / 480$ & 11.3 & 13.1 \\
\hline 2 & $\mathrm{PHN1}_{95 \%} \mathrm{El}_{5 \%}$ & 368 & $405 / 537$ & 1.3 & 13.1 \\
\hline 3 & $\mathrm{PHN1}_{90 \%} \mathrm{E} 1_{10 \%}$ & 363 & $407 / 612$ & 2.2 & 7.7 \\
\hline 4 & $\mathrm{PHN1}_{85 \%} \mathrm{E}_{15 \%}$ & 363 & 410 & 10.2 & 7.7 \\
\hline 5 & $\mathrm{PHNl}_{80 \%} \mathrm{El}_{20 \%}$ & 367 & 408 & 12.8 & 4.8 \\
\hline 6 & $\mathrm{PHN1}_{95 \%} \mathrm{E} 2_{5 \%}$ & 367 & 409 & 9.3 & 10.3 \\
\hline 7 & $\mathrm{PHN1}_{90 \%} \mathrm{E} 2_{10 \%}$ & 371 & 408 & 11.4 & 7.5 \\
\hline 8 & $\mathrm{PHN1}_{85 \%} \mathrm{E} 2_{15 \%}$ & 371 & 409 & 8.8 & 5.0 \\
\hline 9 & $\mathrm{PHN1}_{80 \%} \mathrm{E} 2_{20 \%}$ & 366 & 410 & 10.4 & 4.6 \\
\hline 10 & $\mathrm{PBT}^{\mathrm{e}}$ & 371 & 408 & 2 & 31 \\
\hline
\end{tabular}

Table 2. Thermal property parameters of the poly(ether ester)s. ${ }^{\text {a }}$ Temperature at which $5 \%$ weight loss. ${ }^{\mathrm{b}}$ Temperature for maximum degradation rate. ${ }^{\mathrm{c}}$ Remaining weight at $800{ }^{\circ} \mathrm{C}$. ${ }^{\mathrm{d}}$ Glass transition temperatures $\left(T_{\mathrm{g}}\right)$ taken as the inflection points of the second heating DSC traces of precipitated samples at a heating/cooling rate of $10{ }^{\circ} \mathrm{C} / \mathrm{min}$. ${ }^{\mathrm{e}}$ The data of poly(butylene terephthalate) (PBT) here was referenced from others ${ }^{34}$.

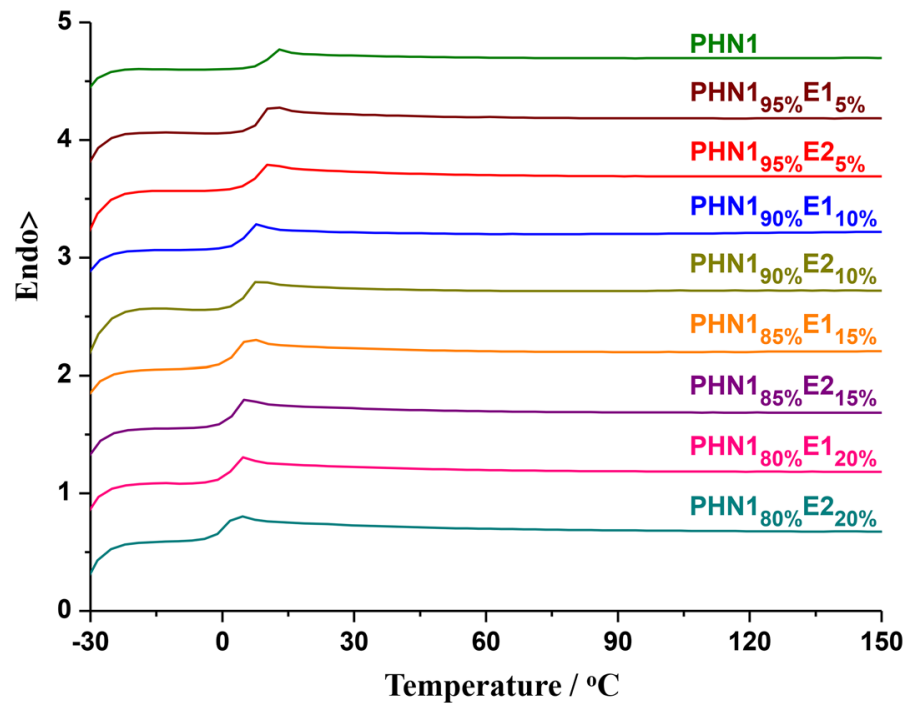

Figure 5. The second heating DSC curves for the poly(ether ester) samples carried out from -30 to $150{ }^{\circ} \mathrm{C}$ at a heating/cooling rate of $10^{\circ} \mathrm{C} / \mathrm{min}$.

Both $P H N 1_{1-\mathrm{x}} \mathrm{E} 1_{\mathrm{x}}$ and $\mathrm{PHN} 1_{1-\mathrm{x}} \mathrm{E} 2_{\mathrm{x}}$ were found to feature obvious glass transition with $T_{\mathrm{g}}$ values ranging from 4.6 to $13.1{ }^{\circ} \mathrm{C}$, which have a progressing decrease trend with the gradual increase of eugenol-based composition, thus caused many free volumes for segmental motion and low $T_{\mathrm{g}} . \mathrm{PHN1} 1_{1-\mathrm{x}} \mathrm{E} 1_{\mathrm{x}}$ had a slightly higher $T_{\mathrm{g}}$ value than $\mathrm{PHN}_{1-\mathrm{x}} \mathrm{E} 2_{\mathrm{x}}$ when the content of eugenol-derived composition is the same, suggesting that $\mathrm{PHN} 1_{1-\mathrm{x}} \mathrm{E} 2_{\mathrm{x}}$ features a better flexibility than $\mathrm{PHN} 1_{1-\mathrm{x}} \mathrm{E} 1_{\mathrm{x}}$. The single glass transition in the second heating run for both two series of copoly(ether ester)s suggested that these samples could not crystallize from the melt during the first cooling run at the given cooling rate of $10^{\circ} \mathrm{C} / \mathrm{min}$. The locally ordered packing of chain segments was not favoured. Although the $T_{\mathrm{g}}$ values gradually decreased with the incorporation of eugenol-derived units, the values changed not so much and were still in the scope of practical applications. Compared with our previous reported 1,10-decanediolbased copoly (ether ester)s $\left(T_{\mathrm{g}}<-8^{\circ} \mathrm{C}\right)^{26}$, the $T_{\mathrm{g}}$ values $\left(>4.5^{\circ} \mathrm{C}\right)$ of 1,6 -hexanediol-based materials in this study has obvious improvement, which is beneficial for applying in a broad range of temperature.

Powder X-ray diffraction analysis. In order to verify and reinforce the above DSC results and further study their crystalline ability of this kind of materials, powder wide-angle X-ray diffraction analysis (WXRD) was performed. The WXRD traces were depicted in Fig. 6 and Supplementary Fig. S20, and the diffraction data were collected in Table 3. All the samples were not able to form well discrete diffraction peaks characteristic of amorphous materials. The scattering pattern for PHN1 was featured by three reflections at $19.04^{\circ}, 21.92^{\circ}$, and $25.66^{\circ}$, respectively, which corresponded to the triclinic crystal structure just like displayed by $\mathrm{PBT}^{35,36}$. Almost the same diffraction pattern was observed for all the poly(ether ester) materials when the diffraction angles and relative intensities were considered, indicating the crystalline mode of PHN1 was maintained in the copoly(ether 


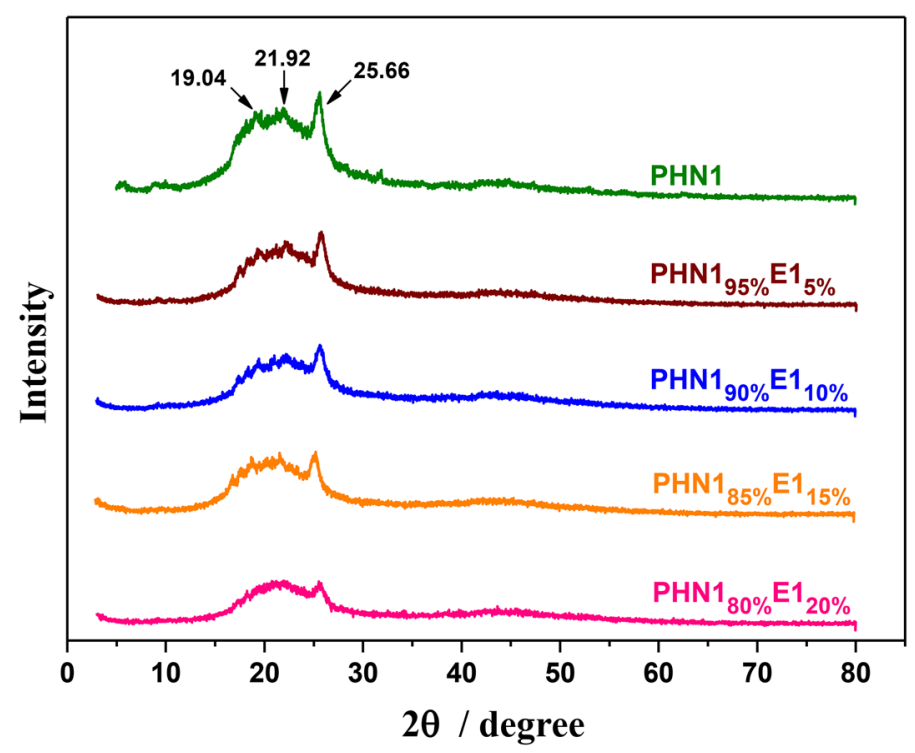

Figure 6. Powder WXRD profiles for PHN1 and $\mathrm{PHN}_{1-\mathrm{x}} \mathrm{E} 1_{\mathrm{x}}$.

\begin{tabular}{|c|c|c|c|c|c|}
\hline \multirow{3}{*}{$\begin{array}{l}\text { Entry } \\
1\end{array}$} & \multirow{3}{*}{$\begin{array}{l}\text { Polymers } \\
\text { PHN1 }\end{array}$} & \multicolumn{4}{|c|}{ X-ray diffraction data } \\
\hline & & \multicolumn{3}{|c|}{$2 \theta\left({ }^{\circ}\right)^{\mathrm{a}}$} & \multirow{2}{*}{\begin{tabular}{|l}
$\boldsymbol{X}_{\mathbf{c}}^{\mathbf{b}}$ \\
0.22 \\
\end{tabular}} \\
\hline & & $19.04 \mathrm{~m}$ & $21.92 \mathrm{~m}$ & $25.66 \mathrm{~s}$ & \\
\hline 2 & $\mathrm{PHN1}_{95 \%} \mathrm{E}_{5 \%}$ & $19.04 \mathrm{~m}$ & $21.92 \mathrm{~m}$ & $25.66 \mathrm{~s}$ & 0.19 \\
\hline 3 & PHN1 $_{90 \%} \mathrm{E} 1_{10 \%}$ & $19.04 \mathrm{~m}$ & $21.92 \mathrm{~m}$ & $25.66 \mathrm{~s}$ & 0.18 \\
\hline 4 & $\mathrm{PHN1}_{85 \%} \mathrm{E}_{15 \%}$ & $19.04 \mathrm{~m}$ & $21.92 \mathrm{~m}$ & $25.66 \mathrm{~s}$ & 0.16 \\
\hline 5 & $\mathrm{PHN1}_{80 \%} \mathrm{El}_{20 \%}$ & $19.04 \mathrm{w}$ & $21.92 \mathrm{w}$ & $25.66 \mathrm{~m}$ & 0.15 \\
\hline 6 & $\mathrm{PHN}_{95 \%} \mathrm{E} 2_{5 \%}$ & $19.04 \mathrm{~m}$ & $21.92 \mathrm{~m}$ & $25.66 \mathrm{~s}$ & 0.18 \\
\hline 7 & PHN1 $_{90 \%} \mathrm{E} 2_{10 \%}$ & $19.04 \mathrm{~m}$ & $21.92 \mathrm{~m}$ & $25.66 \mathrm{~s}$ & 0.16 \\
\hline 8 & $\mathrm{PHN1}_{85 \%} \mathrm{E} 2_{15 \%}$ & $19.04 \mathrm{w}$ & $21.92 \mathrm{w}$ & $25.66 \mathrm{~m}$ & 0.15 \\
\hline 9 & $\mathrm{PHN}_{80 \%} \mathrm{E} 2_{20 \%}$ & $19.04 \mathrm{w}$ & $21.92 \mathrm{w}$ & $25.66 \mathrm{~m}$ & 0.13 \\
\hline
\end{tabular}

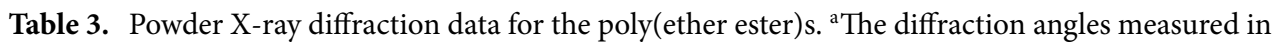
powder diffraction patterns for samples coming directly from precipitation in methanol and dried overnight. Intensities visually estimated as follows: $m$ medium; $s$ strong; $w$ weak. ${ }^{\mathrm{b}}$ Crystallinity index $\left(X_{c}\right)$ calculated as the quotient between crystalline area and total area. Crystalline and amorphous areas in the X-ray diffraction pattern were quantified using PeakFit v4.12 software.

ester)s. The crystallinity values can be calculated as the quotient between crystalline area and total area of the diffraction traces. The copoly(ether ester)s were found to be semi-crystalline and the crystallinities $\left(X_{c}\right)$ decreased with the increase of eugenol-derived composition. The discrepancy of material attribute from DSC and WXRD analysis could be ascribed to the difference of treatment method. The samples for WXRD were directly from precipitation in methanol, resulting in a certain degree of crystallization. The X-ray diffraction results confirmed that such materials still have slightly crystalline properties, rather than completely amorphous materials. The crystallinities gradually decrease with the insertion of eugenol-derived units.

Stress-strain behaviour. Mechanical properties (strength, toughness, ductility, etc.) are primary parameters to be considered for practical applications. To further study the synergistic effect of nipagin and eugenolbased components on mechanical properties, tensile assays of $P H N 1_{1-\mathrm{x}} \mathrm{E} 1_{\mathrm{x}}$ and $\mathrm{PHN1} 1_{1-\mathrm{x}} \mathrm{E} 2_{\mathrm{x}}$ copoly(ether ester)s were performed on dumb-bell shaped specimens $\left(12 \times 2 \times 0.5 \mathrm{~mm}^{3}\right)$, which were prepared by casting the chloroform solution $(0.1 \mathrm{~g} / \mathrm{mL})$. The stress-stain curves were depicted in Fig. 7 and the mechanical property data were summarized in Table 4. Young's modulus and tensile strength were found to decrease with the increase of eugenol-derived units in each series of samples. Furthermore, Young's modulus and tensile strength for $\mathrm{PHN} 1_{1-\mathrm{x}} \mathrm{E} 1_{\mathrm{x}}$ was slightly higher than those of $\mathrm{PHN}_{1-\mathrm{x}} \mathrm{E} 2_{\mathrm{x}}$ when the content of eugenol-derived composition was the same. However, the elongations at break firstly decrease and then increase with the content of eugenol-derived composition increasing. For example, elongations at break decreased from 14.5\% for PHN1 (the data of PHN1 here are original $)^{37}$ to $7.0 \%$ for $\mathrm{PHN}_{90 \%} \mathrm{E}_{10 \%}$, and then increased to $10.0 \%$ for $\mathrm{PHN1} 1_{80 \%} \mathrm{E} 1_{20 \%}$. The elongation at break didn't exhibit the same trends as the Young's modulus and tensile strength do. This may be ascribed to the 
(a)
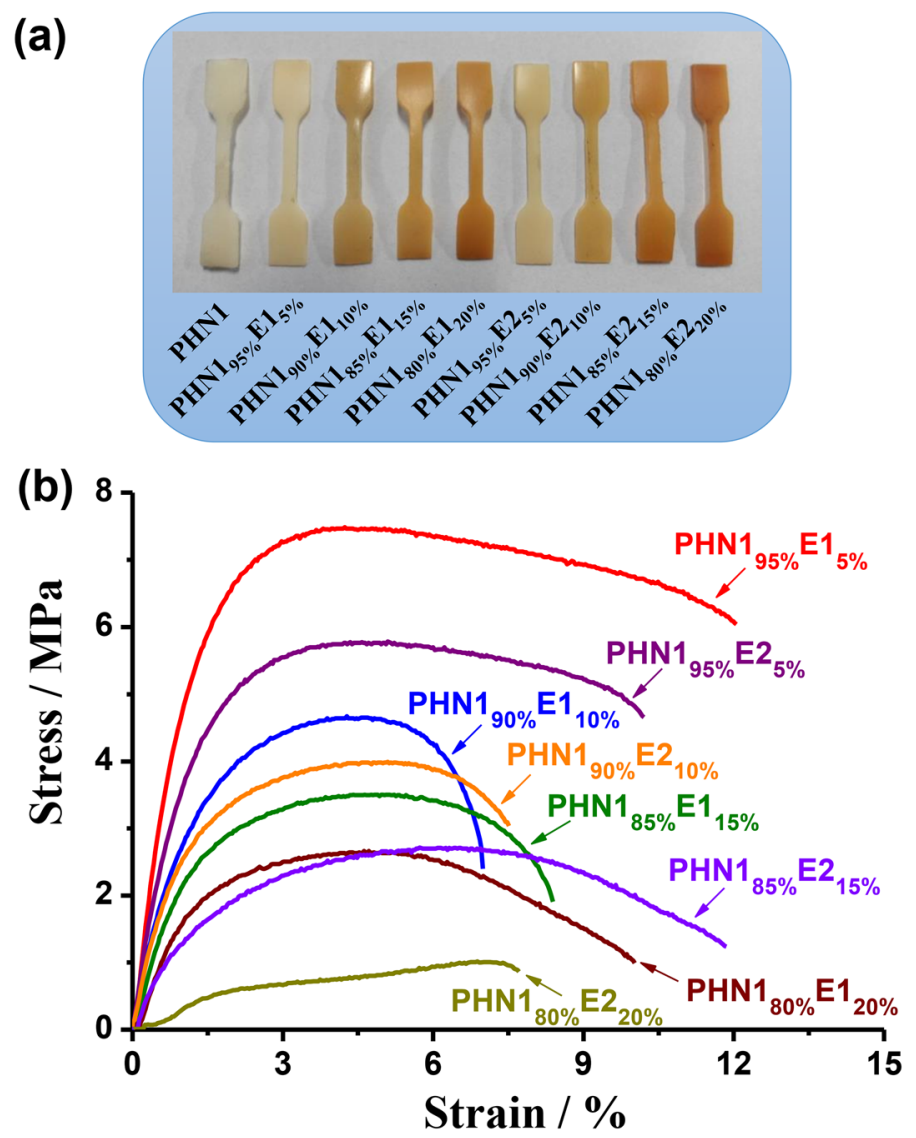

Figure 7. Stress-strain samples (a) and curves (b) of the poly(ether ester)s.

\begin{tabular}{|c|c|c|c|c|}
\hline \multirow[b]{2}{*}{ Entry } & \multirow[b]{2}{*}{ Polymers } & \multicolumn{3}{|l|}{ Mechanical properties $^{b}$} \\
\hline & & Young's modulus (MPa) & Tensile strength (MPa) & Elongation at break (\%) \\
\hline 1 & PHN1 $^{\mathrm{a}}$ & $696 \pm 24$ & $17.2 \pm 1.5$ & $14.5 \pm 2.2$ \\
\hline 2 & $\mathrm{PHN1}_{95 \%} \mathrm{E} 1_{5 \%}$ & $240.0 \pm 14$ & $7.5 \pm 1.2$ & $12.1 \pm 4.2$ \\
\hline 3 & $\mathrm{PHN1}_{90 \%} \mathrm{E} 1_{10 \%}$ & $146.7 \pm 12$ & $4.7 \pm 2.1$ & $7.0 \pm 3.6$ \\
\hline 4 & $\mathrm{PHN1}_{85 \%} \mathrm{El}_{15 \%}$ & $110.0 \pm 16$ & $3.5 \pm 1.5$ & $8.4 \pm 5.0$ \\
\hline 5 & $\mathrm{PHN1}_{80 \%} \mathrm{El}_{20 \%}$ & $83.3 \pm 11$ & $2.7 \pm 1.8$ & $10.0 \pm 4.5$ \\
\hline 6 & $\mathrm{PHN1}_{95 \%} \mathrm{E} 2_{5 \%}$ & $183.3 \pm 28$ & $5.8 \pm 1.5$ & $10.2 \pm 2.4$ \\
\hline 7 & $\mathrm{PHN1}_{90 \%} \mathrm{E} 2_{10 \%}$ & $123.3 \pm 25$ & $4.0 \pm 1.7$ & $7.5 \pm 3.2$ \\
\hline 8 & $\mathrm{PHN1}_{85 \%} \mathrm{E} 2_{15 \%}$ & $57.7 \pm 12$ & $2.7 \pm 0.8$ & $11.9 \pm 4.8$ \\
\hline 9 & $\mathrm{PHN1}_{80 \%} \mathrm{E} 2_{20 \%}$ & $33.3 \pm 8$ & $1.0 \pm 0.6$ & $7.7 \pm 4.6$ \\
\hline 10 & $\mathrm{PBT}^{\mathrm{c}}$ & $841 \pm 15$ & $42 \pm 5$ & $14 \pm 3$ \\
\hline
\end{tabular}

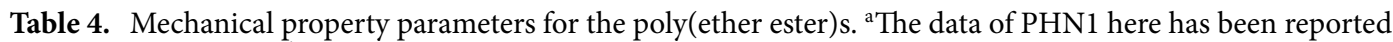
in a previous report ${ }^{36}$. ${ }^{b}$ Young's modulus, tensile strength and elongation at break were calculated by averaging the data from three parallel test on dumb-bell shaped specimens (dimensions: $12 \times 2 \times 0.5 \mathrm{~mm}^{3}$ ) obtained from the casting of chloroform solutions at a concentration of $0.1 \mathrm{~g} / \mathrm{mL}$. ${ }^{c}$ The data of poly(butylene terephthalate) (PBT) here was referenced from others ${ }^{34}$.

asymmetrical nature of eugenol-derived composition, leading to the difficult stacking and loose entanglement of polymer chains. Consequently, Young's modulus and tensile strength decreases with the insertion of eugenolderived composition, while the elongation at break did not feature the same variation tendency. Although PHN1 seems to feature the best mechanical properties (Young's modulus, tensile strength and elongation) than those of copolymerized products, the necessity of copolymerization of nipagin and eugenol-derived monomers is also significant. Nipagin and eugenol are two structurally different building blocks, which will have significant influence on thermal $\left(T_{\mathrm{g}}, T_{5 \%}\right)$, crystalline (crystallinity), and mechanical properties (modulus, strength and ductil- 
ity), which can be tailored for a broad range of applications, such as rubbery and elastomers, etc. depending on the application scenarios.

When compared with the widely-used petroleum-based poly(butylene terephthalate) (PBT) (Table 4, entry $10)^{34}$, the polymer materials in this study presented inferior tensile strength and Young's modulus. This was largely attributed to the insertion of eugenol-derived composition impeding the crystallization of copoly(ether ester)s significantly, together with tunable elongation at break. Although we initially targeted the substitutes of petroleum-based dimethyl terephthalate (DMT) and its derived PBT-like materials, the properties presented in this study were opposite. PBT are often used as food packaging materials, which require high $T_{\mathrm{g}}$, young modulus, and strength values, as well as specific barrier properties, but the polymer materials in this work are appropriate for other application scenarios (elastomer and rubbery), thanks to their modulated mechanical properties by insertion of disparate components. From the point of renewability, this is significant to broaden the types of polymer materials and application fields from bio-based starting materials. The harmony synergistic effect of nipagin and eugenol-derived composition could modulate the properties of such polymer materials in desired application fields.

\section{Conclusions}

In order to prepare further sustainable and practical polymer materials from naturally occurring biomass, renewable nipagin and eugenol-based aromatic copoly(ether ester) materials were synthesized via the melt polycondensation method. The effect of introduction of eugenol-derived units on thermal, crystalline, and mechanical properties was emphatically studied. TGA results revealed that the copoly(ether ester)s featured fairly high thermal stability despite the content of eugenol-derived composition reached $20 \%$. DSC and WXRD data suggested the amorphous nature for both homopoly(ether ester) and copoly(ether ester)s, regardless of the content of highly asymmetrical eugenol-based composition. Young's modulus and tensile strengths were also found a decreasing tendency with the insertion of eugenol-based composition. More importantly, elongation at break can be tunable via the different content of eugenol-based composition. The cooperative interaction of renewable nipagin and eugenol-derived building blocks provides a practical and suitable way to obtain polymeric materials with desired performance and suitable for various application scenarios.

\section{Materials and methods}

Reagents and materials. Nipagin (99\%, Aladdin, Shanghai, China), eugenol (99\%, Aladdin), methyl thioglycolate (99\%, Aladdin), methyl chloroacetate (98\%, Aladdin), 2,2-dimethoxy-2-phenylacetophenone (DMPA) (99\%, Aladdin) and tetrabutyl titanate (TBT) (99.5\%, Aladdin), 1,4-dibromobutane (98\%, J\&K Scientific, Beijing, China), and 1,6-hexanediol (98\%, $J \& K$ Scientific) were used as received. All solvents (Tianjin Chemical Reagent Co., Ltd, Tianjin, China) were analytical grade and used as received without further purification. Silicagel slices used for thin-layer chromatography (TLC) were purchased from Qingdao Haiyang Chemical Co. Ltd (Qingdao, China).

General instrumentation. ${ }^{1} \mathrm{H}$ NMR and ${ }^{13} \mathrm{C}$ NMR spectra were recorded in $\mathrm{CDCl}_{3}$ at $25{ }^{\circ} \mathrm{C}$ on a Bruker AVANCE III NMR spectrometer operating at $400 \mathrm{MHz}$ and $100.6 \mathrm{MHz}$, respectively. Fourier transform infrared spectra (FTIR) were recorded on a Bio-Rad FTS6000 spectrophotometer at $25^{\circ} \mathrm{C}$. Polymer samples were prepared by grinding the polymeric materials adequately with $\mathrm{KBr}$ powder, followed by compressing the mixture to form a pellet. The molecular weights and polydispersity $(\nexists)$ values of the samples were determined by gel permeation chromatography (GPC, Waters 2414 differential refraction detector) at $35^{\circ} \mathrm{C}$. Tetrahydrofuran (THF) was used as the eluent at a flow rate of $1.0 \mathrm{~mL} / \mathrm{min}$. The average molecular weights were calibrated against monodisperse polystyrene (PS) standards. Thermogravimetric analysis (TGA) was carried out using a NETZSCH TG209 instrument. In a typical run, polymer sample was heated from 25 to $800{ }^{\circ} \mathrm{C}$ under a nitrogen atmosphere at a rate of $10^{\circ} \mathrm{C} / \mathrm{min}$. The temperature leading to $5 \%$ weight loss $\left(T_{5 \%}\right)$, temperature for maximum degradation rate $\left(T_{\max }\right)$, and residue weight $(\%)$ at $800{ }^{\circ} \mathrm{C}$ were recorded. Differential scanning calorimetric (DSC) analysis was carried out by a Mettler-Toledo DSC Q100 calorimeter from TA Instruments. Polymer sample after drying was first heated from room temperature to $150^{\circ} \mathrm{C}$ and hold at this temperature for 10 min to eliminate thermal history, then cooled to $-30^{\circ} \mathrm{C}$. Glass transition temperature $\left(T_{\mathrm{g}}\right)$ was observed from the second heating run. All runs were carried out at a rate of $10{ }^{\circ} \mathrm{C} \mathrm{min}{ }^{-1}$. Indium was used as the calibration standards for temperature. Wide X-ray diffraction (WXRD) patterns were recorded on a D/max-2500 diffractometer using CuKa radiation with a wavelength of $0.1542 \mathrm{~nm}$ for dried powder samples. Crystallinity $\left(X_{c}\right)$ was calculated as the quotient between crystalline area and total area. Crystalline and amorphous areas in the X-ray diffraction pattern were quantified by the PeakFit v4.12 software (SeaSolve Software Inc.) with multi-functions (automatic baseline correction (Linear, D2), deduction of reductant peaks, AutoFit (Savitzky-Golay smoothing, Gauss amplification), AutoScan, etc.). Tensile assays were performed at a stretching rate of $50 \mathrm{~mm} / \mathrm{min}$ at $25^{\circ} \mathrm{C}$ on a Testometric AX Universal Strength Testing Machine.

Preparation of nipagin and eugenol-based copoly(ether ester)s. PHN1 homopoly(ether ester), $\mathrm{PHN}_{1-\mathrm{x}} \mathrm{E} 1_{\mathrm{x}}$, and $\mathrm{PHN} 1_{1-\mathrm{x}} \mathrm{E} 2_{\mathrm{x}}(\mathrm{x}=0 \%, 5 \%, 10 \%, 15 \%, 20 \%)$ copoly(ether ester)s were prepared from the mixtures of N1, E1 or E2, and 1,6-hexanediol with the pre-calculated stoichiometric composition. The polymerization was performed in a $25 \mathrm{~mL}$ Schleck round-bottom flask equipped with a nitrogen inlet, a vacuum distillation outlet, and a magnetic stirrer bar. The polymerization scheme is illustrated in Fig. 1. A slight excess molar ratio of diesters to diol (1:1.05) was employed to ensure complete polymerization of ester groups and hydroxyl termination. Tetrabutyl titanate (TBT, $0.6 \%$ molar relative to diester) was used as the catalyst. Before transesterification, the system was purged with nitrogen for $15 \mathrm{~min}$ to ensure no oxygen remaining and to avoid being oxidized 
during polymerization. Transesterification was carried out under a low nitrogen flow at $140-180{ }^{\circ} \mathrm{C}$ for $3-5 \mathrm{~h}$. Polycondensation was then carried out under a $0.03-0.06$ mbar vacuum at $180-200{ }^{\circ} \mathrm{C}$ for $3-5 \mathrm{~h}$ until stirrer bar was stuck, suggesting the completion of polymerization. The reaction mixture was cooled down to room temperature, while normal pressure was recovered with nitrogen to prevent degradation of product. The crude product was dissolved in a minimum amount of chloroform and precipitated in an excess of methanol to remove oligomers and the excess diols. Final product was collected by filtration, thoroughly washed with methanol, and dried in vacuo overnight.

PHN1 homopoly(ether ester). $\quad{ }^{1} \mathrm{H}$ NMR $\left(400 \mathrm{MHz}, 25^{\circ} \mathrm{C}, \mathrm{CDCl}_{3}\right): \delta=7.99-7.97(\mathrm{~m}, 2 \mathrm{H}, \mathrm{Ar}-\mathrm{H}), 6.91-$ $6.89(\mathrm{~m}, 2 \mathrm{H}, \mathrm{Ar}-\mathrm{H}), 4.66$ (s, 2H, $\left.-\mathrm{O}-\mathrm{CH}_{2}-\mathrm{CO}-\right), 4.27-4.17\left(\mathrm{~m}, 4 \mathrm{H},-\mathrm{COO}-\mathrm{CH}_{2}-\right), 1.76-1.62\left(\mathrm{~m}, 4 \mathrm{H},-\mathrm{COOCH}_{2^{-}}\right.$ $\left.\mathrm{CH}_{2}-\right), 1.49-1.25\left(\mathrm{~m}, 4 \mathrm{H},-\mathrm{COOCH}_{2} \mathrm{CH}_{2}-\mathrm{CH}_{2}-\right)$ ppm; ${ }^{13} \mathrm{C} \mathrm{NMR}\left(100.6 \mathrm{MHz}, 25{ }^{\circ} \mathrm{C}, \mathrm{CDCl}_{3}\right): \delta=168.02$ $\left(-\mathrm{OCH}_{2}-\mathrm{CO}-\right), 165.68$ (Ar-CO-), 161.13 (Ar-C), 131.23 (Ar-C), 123.47 (Ar-C), 113.91 (Ar-C), 64.98-64.78 (m, -O-CH ${ }_{2}$-CO-), 64.34-64.23 (m, -COO- $\left.\mathrm{CH}_{2}-\right)$, 28.34-28.00 (m, - $\left.\mathrm{OCH}_{2}-\mathrm{CH}_{2}-\right), 25.45-24.98\left(\mathrm{~m},-\mathrm{OCH}_{2} \mathrm{CH}_{2}-\right.$ $\left.\mathrm{CH}_{2^{-}}\right)$ppm; FTIR: 2949, $1781(\mathrm{C}=\mathrm{O}), 1711(\mathrm{C}=\mathrm{O}), 1606,1510,1253,1170,1105,977,848,770,697 \mathrm{~cm}^{-1}$.

$\mathrm{PHN1}_{1-\mathrm{x}} \mathrm{E} 1_{\mathrm{x}}$ copoly(ether ester)s. ${ }^{1} \mathrm{H} \mathrm{NMR}\left(400 \mathrm{MHz}, 25{ }^{\circ} \mathrm{C}, \mathrm{CDCl}_{3}\right): \delta=7.95-7.93\{\mathrm{~m},(1-\mathrm{x}) \cdot 2 \mathrm{H}$; $\mathrm{Ar}-H\}, 6.88-6.86\{\mathrm{~m},(1-\mathrm{x}) \cdot 2 \mathrm{H} ; \mathrm{Ar}-H\}, 6.72-6.68(\mathrm{~m}, \mathrm{x} \cdot 2 \mathrm{H} ; \mathrm{Ar}-H), 6.63-6.61(\mathrm{~m}, \mathrm{x} \cdot \mathrm{H} ; \mathrm{Ar}-\mathrm{H}), 4.63\{\mathrm{~s},(1-\mathrm{x}) \cdot 2 \mathrm{H}$; ArO-CH $-\mathrm{CO}-\}, 4.60$ (s, x.2H; ArO-CH $-\mathrm{CO}-), 4.30-4.09\left\{\mathrm{~m},(1-\mathrm{x}) \cdot 4 \mathrm{H} ;-\mathrm{COO}-\mathrm{CH}_{2}-\right\}, 4.15-4.02(\mathrm{~m}, \mathrm{x} \cdot 4 \mathrm{H}$; $-\mathrm{COO}-\mathrm{CH}_{2}-$ ), $3.81\left(\mathrm{~s}, \mathrm{x} \cdot 3 \mathrm{H} ; \mathrm{ArO}-\mathrm{CH}_{3}\right), 3.16\left(\mathrm{~s}, \mathrm{x} \cdot 2 \mathrm{H}\right.$; $\left.-\mathrm{S}-\mathrm{CH}_{2}-\mathrm{CO}-\right), 2.62-2.57$ (m, x.4H; $\mathrm{Ar}-\mathrm{CH}_{2}-\mathrm{CH}_{2}-\mathrm{CH}_{2}-$ S-), $1.88-1.81\left\{\mathrm{q},{ }^{3} J(\mathrm{H}, \mathrm{H})=8.0 \mathrm{~Hz}, \mathrm{x} \cdot 2 \mathrm{H} ; \mathrm{ArCH}_{2}-\mathrm{CH}_{2}-\mathrm{CH}_{2} \mathrm{~S}-\right\}, 1.79-1.65\left\{\mathrm{~m},(1-\mathrm{x}) \cdot 2 \mathrm{H} ; \mathrm{ArCOOCH}_{2}-\mathrm{CH}_{2}-\right\}$, $1.65-1.52\left\{\mathrm{~m},(1-\mathrm{x}) \cdot 2 \mathrm{H}+\mathrm{x} \cdot 4 \mathrm{H} ;-\mathrm{COOCH}_{2}-\mathrm{CH}_{2}-\right\}, 1.50-1.17\left\{\mathrm{~m},(1-\mathrm{x}) \cdot 4 \mathrm{H}+\mathrm{x} \cdot 4 \mathrm{H} ;-\mathrm{COOCH}_{2} \mathrm{CH}_{2}-\mathrm{CH}_{2}-\right\} \mathrm{ppm}$; ${ }^{13} \mathrm{C} \mathrm{NMR}\left(100.6 \mathrm{MHz}, 25^{\circ} \mathrm{C}, \mathrm{CDCl}_{3}\right): \delta=170.48\left(-\mathrm{SCH}_{2}-\mathrm{CO}-\right), 169.18\left(\mathrm{ArOCH}_{2}-\mathrm{CO}-\right), 168.29\left(\mathrm{ArOCH}_{2}-\mathrm{CO}-\right)$, 166.02 (Ar-CO-), 161.38 (Ar-C), 149.54 (Ar-C), 145.59 (Ar-C), $135.74(\mathrm{Ar}-C), 131.51$ (Ar-C), $123.82(\mathrm{Ar}-C)$, 120.23 (Ar-C), $114.63(\mathrm{Ar}-\mathrm{C}), 114.17(\mathrm{Ar}-\mathrm{C}), 112.60(\mathrm{Ar}-\mathrm{C}), 66.68$ and $65.11\left(\mathrm{ArO}-\mathrm{CH}_{2}-\mathrm{CO}-\right), 65.38-64.50$ (-COO- $\mathrm{CH}_{2}-$ ), 55.87 (ArO- $\left.\mathrm{CH}_{3}\right), 34.15$ (-S-CH $\left.2-\mathrm{CO}-\right)$, 33.59 ( $\left.\mathrm{Ar}-\mathrm{CH}_{2}-\mathrm{CH}_{2} \mathrm{CH}_{2} \mathrm{~S}-\right), 31.99\left(-\mathrm{S}-\mathrm{CH}_{2}-\mathrm{CH}_{2} \mathrm{CH}_{2} \mathrm{Ar}\right)$, $30.50\left(\mathrm{ArCH}_{2}-\mathrm{CH}_{2}-\mathrm{SCH}_{2}-\right), 28.67-28.54\left(\mathrm{~m},-\mathrm{COOCH}_{2}-\mathrm{CH}_{2}-\right), 28.40-28.27\left(\mathrm{~m},-\mathrm{COOCH}_{2} \mathrm{CH}_{2}-\mathrm{CH}_{2}-\right)$ ppm; FTIR: 2934, 2860, 1756 (C=O), $1703(\mathrm{C}=\mathrm{O}), 1603,1510,1422,1265,1166,1105,1070,974,846,765,693 \mathrm{~cm}^{-1}$.

$\mathrm{PHN1}_{1-\mathrm{x}} \mathrm{E} 2_{\mathrm{x}}$ copoly(ether ester)s. ${ }^{1} \mathrm{H}$ NMR $\left(400 \mathrm{MHz}, 25{ }^{\circ} \mathrm{C}, \mathrm{CDCl}_{3}\right): \delta=7.92-7.90\{\mathrm{~m},(1-\mathrm{x}) \cdot 2 \mathrm{H}$; $\mathrm{Ar}-H\}, 6.85-6.83\{\mathrm{~m},(1-\mathrm{x}) \cdot 2 \mathrm{H} ; \mathrm{Ar}-H\}, 6.73-6.71(\mathrm{~m}, \mathrm{x} \cdot \mathrm{H} ; \mathrm{Ar}-H), 6.63-6.59(\mathrm{~m}, \mathrm{x} \cdot 2 \mathrm{H} ; \mathrm{Ar}-H), 4.59\{\mathrm{~s}$, $\left.(1-\mathrm{x}) \cdot 2 \mathrm{H} ; \mathrm{ArO}-\mathrm{CH}_{2}-\mathrm{CO}-\right\}, 4.19-4.10\left\{\mathrm{~m},(1-\mathrm{x}) \cdot 4 \mathrm{H} ;-\mathrm{COO}-\mathrm{CH}_{2}-\right\}, 4.03-3.97\left\{\mathrm{~m},(1-\mathrm{x}) \cdot 4 \mathrm{H}+\mathrm{x} \cdot 4 \mathrm{H} ; \mathrm{ArO}-\mathrm{CH}_{2^{-}}\right.$ $\mathrm{CH}_{2}$ - and -COO- $\left.\mathrm{CH}_{2}-\right\}, 3.75$ (s, x-6H; $\mathrm{ArO}-\mathrm{CH}_{3}$ ), 3.13 (s, x.4H; -S-CH $-\mathrm{CO}-$ ), 2.67-2.46 (m, x.8H; Ar- $\mathrm{CH}_{2}-$ $\mathrm{CH}_{2}-\mathrm{CH}_{2}-\mathrm{S}-$ ), 2.02-1.88 (m, x.4H; $\left.\mathrm{ArOCH}_{2}-\mathrm{CH}_{2}-\right), 1.88-1.76\left\{\mathrm{q},{ }^{3} \mathrm{~J}(\mathrm{H}, \mathrm{H})=8.0 \mathrm{~Hz}, \mathrm{x} \cdot 4 \mathrm{H} ; \mathrm{ArCH}_{2}-\mathrm{CH}_{2}-\mathrm{CH}_{2} \mathrm{~S}-\right\}$, $1.75-1.63\left\{\mathrm{~m},(1-\mathrm{x}) \cdot 2 \mathrm{H} ; \mathrm{ArCOOCH}_{2}-\mathrm{CH}_{2}-\right\}, 1.62-1.47\left\{\mathrm{~m},(1-\mathrm{x}) \cdot 2 \mathrm{H}+\mathrm{x} \cdot 4 \mathrm{H} ;-\mathrm{COOCH}_{2}-\mathrm{CH}_{2}-\right), 1.46-1.12\{\mathrm{~m}$, $\left.(1-\mathrm{x}) \cdot 4 \mathrm{H}+\mathrm{x} \cdot 4 \mathrm{H} ;-\mathrm{COOCH}_{2} \mathrm{CH}_{2}-\mathrm{CH}_{2}-\right\} \mathrm{ppm} ;{ }^{13} \mathrm{C} \mathrm{NMR}\left(100.6 \mathrm{MHz}, 25{ }^{\circ} \mathrm{C}, \mathrm{CDCl}_{3}\right): \delta=170.29\left(-\mathrm{SCH}_{2}-\mathrm{CO}-\right)$, $168.09\left(\mathrm{ArOCH}_{2}-\mathrm{CO}-\right), 165.78$ (Ar-CO-), $161.22(\mathrm{Ar}-\mathrm{C}), 149.20(\mathrm{Ar}-\mathrm{C}), 146.57(\mathrm{Ar}-\mathrm{C}), 133.87(\mathrm{Ar}-\mathrm{C}), 131.31$ $(\mathrm{Ar}-\mathrm{C}), 123.62(\mathrm{Ar}-\mathrm{C}), 120.13(\mathrm{Ar}-\mathrm{C}), 114.00(\mathrm{Ar}-\mathrm{C}), 113.21(\mathrm{Ar}-\mathrm{C}), 112.20(\mathrm{Ar}-\mathrm{C}), 68.58\left(\mathrm{ArO}-\mathrm{CH}_{2}-\mathrm{CH}_{2}-\right)$, 64.90 (ArO- $\left.\mathrm{CH}_{2}-\mathrm{CO}-\right)$, 64.42-64.31 (-COO- $\left.\mathrm{CH}_{2}-\right)$, $55.71\left(\mathrm{ArO}-\mathrm{CH}_{3}\right), 33.95\left(-\mathrm{S}_{-} \mathrm{CH}_{2}-\mathrm{CO}-\right), 33.39\left(\mathrm{Ar}_{-} \mathrm{CH}_{2^{-}}\right.$ $\left.\mathrm{CH}_{2} \mathrm{CH}_{2} \mathrm{~S}-\right)$, 31.81 (-S- $\left.\mathrm{CH}_{2}-\mathrm{CH}_{2} \mathrm{CH}_{2} \mathrm{Ar}\right), 30.42\left(\mathrm{ArCH}_{2}-\mathrm{CH}_{2}-\mathrm{SCH}_{2}-\right), 28.43-28.15$ (m, $\left.-\mathrm{COOCH}_{2}-\mathrm{CH}_{2}-\right), 25.84$ $\left(\mathrm{ArOCH}_{2}-\mathrm{CH}_{2}-\right)$, 25.53-25.06 (m, $\left.-\mathrm{COOCH}_{2} \mathrm{CH}_{2}-\mathrm{CH}_{2}{ }^{-}\right)$ppm; FTIR: 2935, 2860, $1756(\mathrm{C}=\mathrm{O}), 1708(\mathrm{C}=\mathrm{O})$, $1603,1510,1459,1264,1166,1107,1071,976,847,809,765,693 \mathrm{~cm}^{-1}$.

Received: 11 July 2021; Accepted: 7 December 2021

Published online: 16 December 2021

\section{References}

1. Schutyser, W. et al. Chemicals from lignin: an interplay of lignocellulose fractionation, depolymerisation, and upgrading. Chem. Soc. Rev. 47, 852-908 (2018).

2. Sheldon, R. \& Woodley, J. Role of biocatalysis in sustainable chemistry. Chem. Rev. 118, 801-838 (2018).

3. Mika, L., Cséfalvay, E. \& Németh, Á. Catalytic conversion of carbohydrates to initial platform chemicals: chemistry and sustainability. Chem. Rev. 118, 505-613 (2018).

4. Zhang, L., Liu, Z., Cui, G. \& Chen, L. Biomass-derived materials for electrochemical energy storages. Prog. Polym. Sci. 43, 136-164 (2015).

5. Douka, A., Vouyiouka, S., Papaspyridi, L. \& Papaspyrides, C. A review on enzymatic polymerization to produce polycondensation polymers: The case of aliphatic polyesters, polyamides and polyesteramides. Prog. Polym. Sci. 79, 1-25 (2018).

6. Varma, R. Biomass-derived renewable carbonaceous materials for sustainable chemical and environmental applications. ACS Sustain. Chem. Eng. 7, 6458-6470 (2018).

7. Gallezot, P. Conversion of biomass to selected chemical products. Chem. Soc. Rev. 41, 1538-1558 (2012).

8. Lambert, S. \& Wagner, M. Environmental performance of bio-based and biodegradable plastics: the road ahead. Chem. Soc. Rev. 46, 6855-6871 (2017).

9. Zhu, Y., Romain, C. \& Williams, C. Sustainable polymers from renewable resources. Nature 540, 354-362 (2016).

10. John, G., Nagarajan, S., Vemula, P., Silverman, J. \& Pillai, C. Natural monomers: a mine for functional and sustainable materials-occurrence, chemical modification and polymerization. Prog. Polym. Sci. 92, 158-209 (2019).

11. Wang, Z., Ganewatta, M. \& Tang, C. Sustainable polymers from biomass: bridging chemistry with materials and processing. Prog. Polym. Sci. 101, 101197 (2020).

12. Lummiss, J. et al. Chemical plants: high-value molecules from essential oils. J. Am. Chem. Soc. 134, 18889-18891 (2012).

13. Tomizawa, S., Chuah, J., Matsumoto, K., Doi, Y. \& Numata, K. Understanding the limitations in the biosynthesis of polyhydroxyalkanoate (PHA) from lignin derivatives. ACS Sustain. Chem. Eng. 2, 1106-1113 (2014). 
14. Chen, X. et al. Design, synthesis, and characterization of bent-core mesogen-jacketed liquid crystalline polymers. Macromolecules 39, 517-527 (2006).

15. Chien, C. \& Liu, J. Optical behaviors of cholesteric liquid-crystalline polyester composites with various chiral photochromic dopants. Langmuir 31, 13410-13419 (2015).

16. Faye, I., Decostanzi, M., Ecochard, Y. \& Caillol, S. Eugenol bio-based epoxy thermosets: from cloves to applied materials. Green. Chem. 19, 5236-5242 (2015).

17. Chen, C., Tung, S., Jeng, R., Abu-Omar, M. \& Lin, C. A facile strategy to achieve fully bio-based epoxy thermosets from eugenol. Green. Chem. 21, 4475-4488 (2019).

18. Chen, C., Lin, C., Juang, T., Abu-Omar, M. \& Lin, C. The reaction of activated esters with epoxides for self-curable, highly flexible, $\mathrm{A}_{2} \mathrm{~B}_{2}$ - and $\mathrm{A}_{3} \mathrm{~B}_{3}$-type epoxy compounds. Polym. Chem. 10, 3983-3995 (2019).

19. Teng, N. et al. Making benzoxazine greener and stronger: renewable resource, microwave irradiation, green solvent, and excellent thermal properties. ACS Sustain. Chem. Eng. 7, 8715-8723 (2019).

20. Shi, W. et al. Sustainable preparation of bio-based polybenzoxazine resins from amino acid and their application in $\mathrm{CO}_{2}$ adsorption. ACS Sustain. Chem. Eng. 7, 17313-17324 (2019).

21. Watanabe, H., Takahashi, M., Kihara, H. \& Yoshida, M. Photocurable urushiol analogues bearing methacryloxy-containing side chains. Langmuir 35, 4534-4539 (2019).

22. Breloy, L. et al. $\beta$-Carotene/limonene derivatives/eugenol: green synthesis of antibacterial coatings under visible-light exposure. ACS Sustain. Chem. Eng. 7, 19591-19604 (2019).

23. Hoefling, A., Nguyen, D., Lee, Y., Song, S. \& Theato, P. A sulfur-eugenol allyl ether copolymer: a material synthesized via inverse vulcanization from renewable resources and its application in Li-S batteries. Mater. Chem. Front. 1, 1818-1822 (2017).

24. Hu, K., Zhao, D., Wu, G. \& Ma, J. Synthesis and properties of polyesters derived from renewable eugenol and $\alpha$, $\omega$-diols via a continuous overheating method. Polym. Chem. 6, 7138-7148 (2015).

25. Hu, K., Zhao, D., Wu, G. \& Ma, J. Toughened aromatic poly-(decylene terephthalate) copolyesters with two renewable eugenolbased components via a random copolymerization method. Polym. Chem. 7, 1096-1110 (2016).

26. Hu, K., Zhao, D., Wu, G. \& Ma, J. Bio-based aromatic copoly(ether ester)s with enhanced toughness and degradability: influence of insertion of phenoxy-ether linkage and eugenol-derived composition on properties. J Polym. Sci. Part A: Polym. Chem. 54, 2171-2183 (2016).

27. Martella, D., Parmeggiani, C., Wiersma, D., Piñol, M. \& Oriol, L. The first thiol-yne click chemistry approach for the preparation of liquid crystalline elastomers. J Mater. Chem. C. 3, 9003-9010 (2015).

28. Wilsens, C. et al. Improving stiffness, strength, and toughness of poly ( $\omega$-pentadecalactone) fibers through in situ reinforcement with a vanillic acid-based thermotropic liquid crystalline polyester. Macromolecules 49, 2228-2237 (2016).

29. Japu, C. et al. Bio-based aromatic copolyesters made from 1,6-hexanediol and bicyclic diacetalized D-glucitol. Polym. Chem. 3, 2092-2101 (2012).

30. Burt, S. et al. Production of 1,6-hexanediol from tetrahydropyran-2-methanol by dehydration-hydration and hydrogenation. Green. Chem. 19, 1390-1398 (2017).

31. Warlin, N. et al. A rigid spirocyclic diol from fructose-based 5-hydroxymethylfurfural: synthesis, life-cycle assessment, and polymerization for renewable polyesters and poly(urethane-urea)s. Green. Chem. 21, 6667-6684 (2019).

32. He, J. et al. Synthesis of 1,6-hexanediol from cellulose derived tetrahydrofuran-dimethanol with $\mathrm{Pt}_{-} \mathrm{WO}_{\mathrm{x}} / \mathrm{TiO}_{2}$ Catalysts. ACS Catal. 8, 1427-1439 (2018).

33. Japu, C. et al. D-glucose-derived PET copolyesters with enhanced $T_{\mathrm{g}}$. Polym. Chem. 4, 3524-3536 (2013).

34. Lavilla, C. et al. Bio-based aromatic polyesters from a novel bicyclic diol derived from D-mannitol. Macromolecules 45, 8257-8266 (2012).

35. Japu, C. et al. Bio-based PBT copolyesters derived from D-glucose: influence of composition on properties. Polym. Chem. 5, 3190-3202 (2014).

36. Shen, Z. et al. A study on mediating the crystallization behavior of PBT through intermolecular hydrogen-bonding. RSC Adv. 6 , $17510-17518$ (2016).

37. Hu, K., Zhao, D., Wu, G. \& Ma, J. Aromatic poly(ether ester)s derived from a naturally occurring building block nipagin and linear aliphatic $\alpha$, $\omega$-diols. RSC Adv. 7, 32989-33000 (2017).

\section{Acknowledgements}

The authors gratefully acknowledge the financial support from the Double First-Rate Start-Up Funding (Tianjin, China) for new young teachers (Grant No: 52010326) at Tiangong University.

\section{Author contributions}

K.H. conceived the study and wrote the paper. H.S. and D.Z. contributed in measuring and analysing the data. All authors thoroughly reviewed the manuscript. All authors read and approved the final version of this manuscript.

\section{Competing interests}

The authors declare no competing interests.

\section{Additional information}

Supplementary Information The online version contains supplementary material available at https://doi.org/ 10.1038/s41598-021-03614-Z.

Correspondence and requests for materials should be addressed to K.H.

Reprints and permissions information is available at www.nature.com/reprints.

Publisher's note Springer Nature remains neutral with regard to jurisdictional claims in published maps and institutional affiliations. 
(c) (i) Open Access This article is licensed under a Creative Commons Attribution 4.0 International cc) License, which permits use, sharing, adaptation, distribution and reproduction in any medium or format, as long as you give appropriate credit to the original author(s) and the source, provide a link to the Creative Commons licence, and indicate if changes were made. The images or other third party material in this article are included in the article's Creative Commons licence, unless indicated otherwise in a credit line to the material. If material is not included in the article's Creative Commons licence and your intended use is not permitted by statutory regulation or exceeds the permitted use, you will need to obtain permission directly from the copyright holder. To view a copy of this licence, visit http://creativecommons.org/licenses/by/4.0/.

(C) The Author(s) 2021 